研

究

\title{
$\mathrm{Cu}$ 焼結体の㯏れ防止と強化に及ぼす $\mathrm{ZrO}_{2}$ 微粉添加の効果
}

\author{
武川淳二郎 \\ 石巻専修大学理工学部電子材料工学科, 个 986-8580 石巻市南境新水戸 1.
}

\section{The Densifining and the Strengthening of Sintered Cu Compacts Through the Addition of $\mathrm{ZrO}_{2}$ Fine Powder}

\author{
Junjiro Takekawa \\ Dept. Elec. Mat., Fac. Sci. and Eng., Ishinomaki Senshu University, 1 Shinmito Minamisakai, Ishinomaki 986-9580.
}

Received March 19, 2001

\section{SYNOPSIS}

It has been known that the $\mathrm{Cu}$ powder compacts often swell when sintered in $\mathrm{H}_{2}$ gas, therefore the densification and the strength of the sintered compacts are limited to low levels. In this study $0.1 \sim 1.5$ mass $\% \mathrm{ZrO}_{2}$ fine powder was mixed with $\mathrm{Cu}$ powder in order to prevent the swelling during sintering. These mixed powders were sintered in both $\mathrm{H}_{2}$ and vacuum atmospheres at $850^{\circ} \mathrm{C} \sim 1050^{\circ} \mathrm{C}$.

It was shown that the addition of $\mathrm{ZrO}_{2}$ fine powder was extremely effective on the prevention of the swelling of the $\mathrm{Cu}$ compacts during sintering, and the high densification was obtained. The reason why $\mathrm{ZrO}_{2}$ fine powder prevent the swelling durring sintering could be explaned as follows: it may delay the formation of isolated pores by slowing down the sintering of $\mathrm{Cu}$ powder particles and simultaneously make the deffusion pathes for reaction gaseous. It was also shown that the most effective amounts of $\mathrm{ZrO}_{2}$ fine powder on the densification of $\mathrm{Cu}$ powder increased with increasing sintering temperatures. The addition of $\mathrm{ZrO}_{2}$ fine powder improved the tensile strengths of sintered $\mathrm{Cu}$ compacts because of its function to make the grains fine.

\section{KEYWORDS}

swelling, $\mathrm{ZrO}_{2}$ fine powder, $\mathrm{Cu}$ powder, densification, isolated pore

\section{1 緒言}

銅 $(\mathrm{Cu})$ 粉は鉄粉, ステンレス鋼粉, ニッケル粉等と共に粉 末治金による金属部品の製作に最も一般的に用いられている 粉末である. Cuの融点は $1083^{\circ} \mathrm{C}$ と比較的低いため MIMに用 いるような 4〜5 $\mu \mathrm{m}$ 程度の細かい粉末では $700^{\circ} \mathrm{C}$ 程度の低温 で容易に焼結は起こるが，このような易焼結性の粉末の成形 体においてはしばしば膨れ現象によって焼結体の内部に大き い空隙が生じやすい。この膨れ現象は以下の機構で起こると されている.すなわちC粉はある温度になると急速に焼結か 進行し著しい結晶粒成長が起こるため結晶粒内に孤立した空 隙は空孔の拡散経路となる粒界が無いために収縮できず，逆 にその空隙内に閉じ込められたガス (おもに $\mathrm{H}_{2} \mathrm{O}$ ガスといわ れている)か膨張する”.この膨れを防ぐためには，(1) $\mathrm{H}_{2} \mathrm{O} カ ゙$ 不生成の原因となる銅粉表面の酸化皮膜を還元により完全に 除去する. (2)焼結を高真空中などガスが抜けやすい雲围気で 行う. (3)酸化物の標準生成エネルギーが銅よりも小さい金属
元素を添加する. (4)脱酸性の強い元素(例えばC)の粉末を添 加するリ。などの方法が考えられるがいずれも工業的には必ず しも現実的ではない.

そこで本論では微量の酸化物微粒子をCu粉中に添加, 分散 させることによって燒結の進行をやや鈍らせ，孤立空隙が形 成されるのを遅らせる試みを行った。この微粒子添加は粒成 長を抑えるとともにこれの分散により細いガスの通路を形成 することによって嬅結の際の囍れ防止も可能になることか期 待される.このため特に膨れが起こりやすい平均粒径 $4.5 \mu \mathrm{m}$ の細かいCu粉を選び, これにジルコニア $\left(\mathrm{ZrO}_{2}\right)$ の微粉 $(27 \mathrm{~nm})$ を少量添加することによる効果について検討した.この結果， $\mathrm{ZrO}_{2}$ 微粉添加による膨れ防止効果とこの添加による分散強化 効果も認められたためその結果について報告する。

\section{2 実験方法}

噴霧法で作製した平均粒径 $4.5 \mu \mathrm{m}$ のCu粉（日本アトマイス 


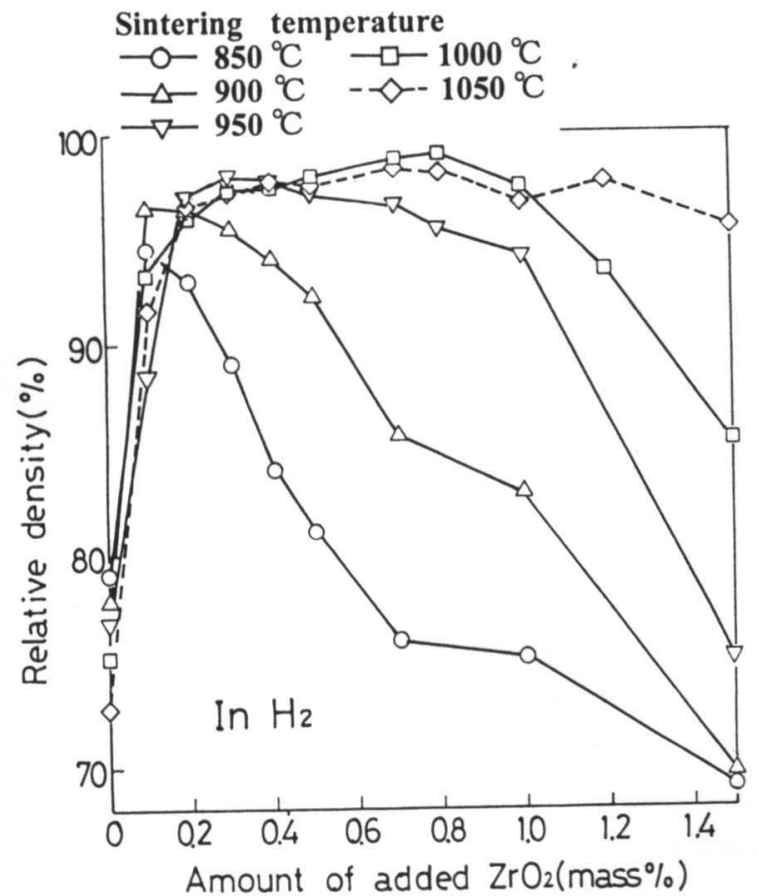

Fig.1 Relation between relative density and the amount of additive $\mathrm{ZrO}_{2}$ fine powder for $\mathrm{Cu}$ compacts sintered at the each temperature for $2 \mathrm{hr}$ in $\mathrm{H}_{2}$.

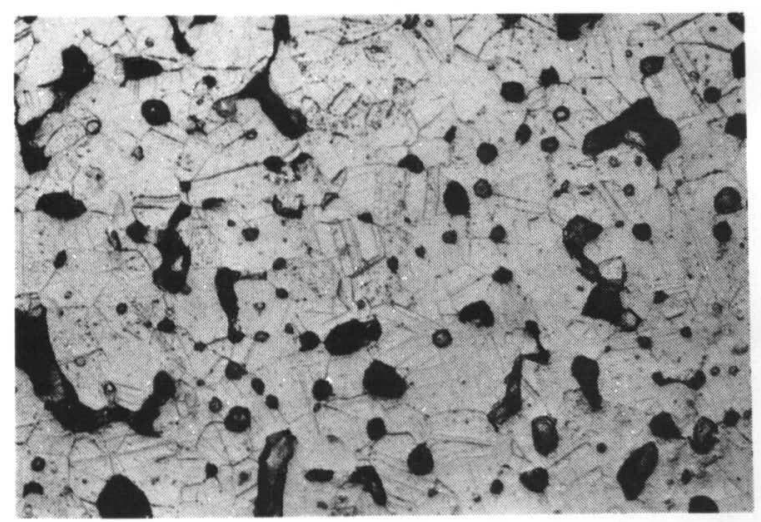

(a) without $\mathrm{ZrO}$, R.D.: $\mathbf{7 8 . 7 9 \%}$

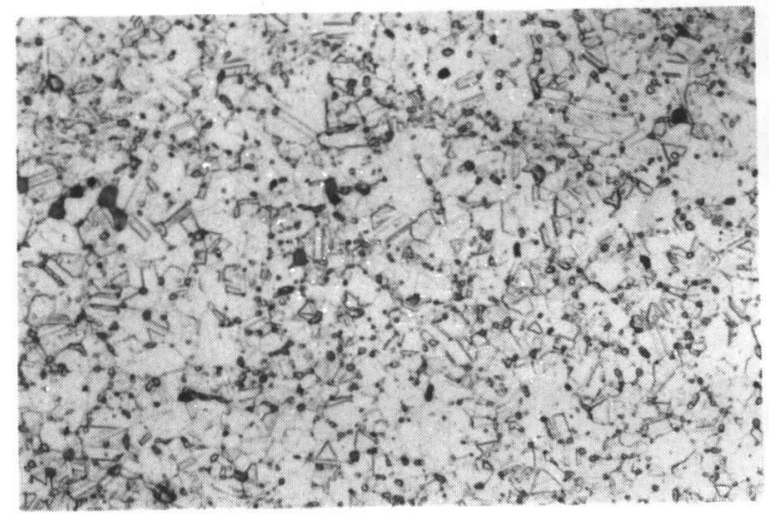

(c) $0.5 \mathrm{mass} \% \mathrm{ZrO}_{2}$, R.D.: $97.41 \%$
加工製)に平均粒径 $27 \mathrm{~nm}$ の $\mathrm{ZrO}_{2}$ 粉末(東洋ソーダ製)を 0.1 1.5 mass\%遠心型ボールミルを用いて混合した.この際いわゆ るメカニカルアロイングが起こらないように低い回転数で粉 末同土を良く混ぜ合わせることに力点を置いてボールミルを 行った.この混合粉を $\mathrm{H}_{2}$ 中で $320^{\circ} \mathrm{C}, 2 \mathrm{~h}$ 還元後, 金型を用い て $130 \mathrm{MPa}$ の圧力で成形して引張り試験片形状の成形体を得 た.つきにこの成形体を水素雾囲気中及び真空中 $\left(2.5 \times 10^{-3} \mathrm{~Pa}\right)$ で $850^{\circ} \mathrm{C} \sim 1050^{\circ} \mathrm{C}$ の各温度で $2 \mathrm{~h}$ 焼結を行った. 焼結の際の加 熱パターンは $250^{\circ} \mathrm{C} / \mathrm{h}$ で目的の温度まで昇温し $2 \mathrm{~h}$ 保持してか ら $300^{\circ} \mathrm{C} / \mathrm{h}$ で降温するこく普通のものを用いた。得られた焼 結体試料について密度測定後, 引張り強さを測定し組織観察 を行った。

\section{3 結果および考察}

\section{$3.1 \mathrm{Cu}$ 焼結体の䋑密化に及ぼす $\mathrm{ZrO}_{2}$ 微粉添加の効果}

Fig.1 水素雾囲気中で各温度で焼結した際の Cu 焼結体の 相対密度に及ぼす $\mathrm{ZrO}_{2}$ 粉の添加量の影響を示した. $\mathrm{ZrO}_{2}$ 添加 により添加しない場合に比べ著しく緻密化することが分かる. すなわち $850^{\circ} \mathrm{C} \sim 1050^{\circ} \mathrm{C}$ の各温度で焼結した結果, $\mathrm{ZrO}_{2}$ を添 加しない焼結体はいずれも激しい膨れを起こし相対密度は $80 \%$ 前後に止まったが, 0.2 mass\% 以上の $\mathrm{ZrO}_{2}$ の添加により

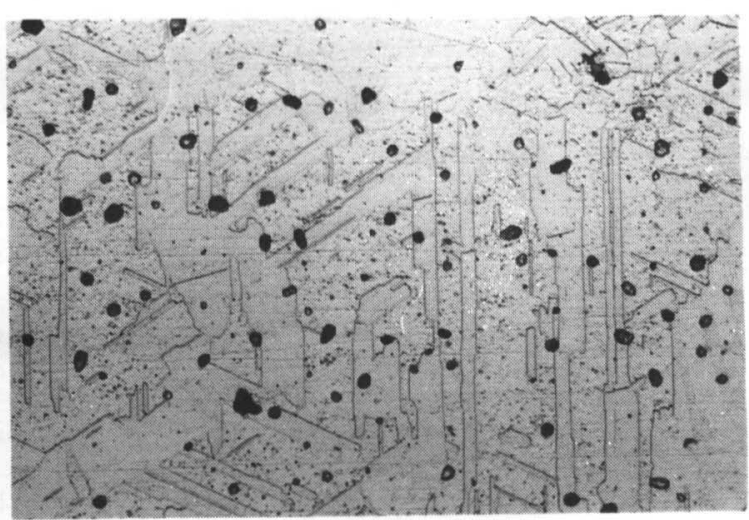

(b) $0.2 \mathrm{mass} \% \mathrm{ZrO}$, R.D.: $96.93 \%$

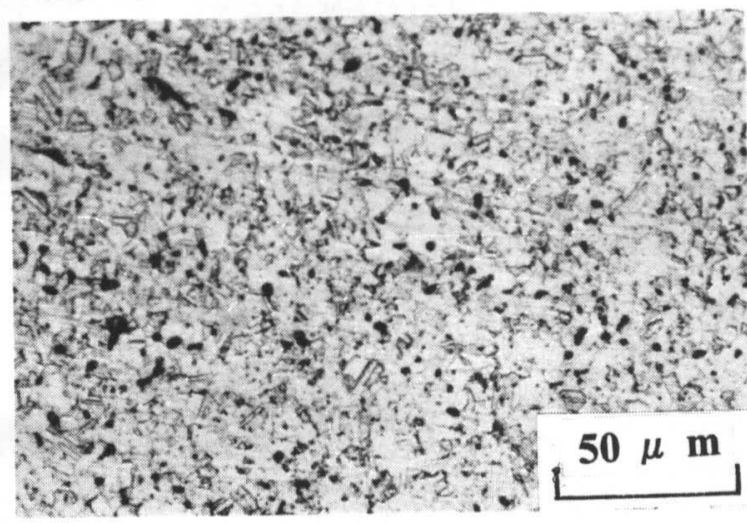

(d) 0.7 mass $\% \mathrm{ZrO}_{2}$, R.D.: $96.76 \%$

Fig.2 Microstructural changes in Cu compacts sintered at $950^{\circ} \mathrm{C}$ in $\mathrm{H}_{2}$, where (a) without $\mathrm{ZrO}_{2}$, (b) $0.2 \mathrm{mass}_{2} \mathrm{ZrO}$, (c) $0.5 \mathrm{mass} \% \mathrm{ZrO}$, (d) $0.7 \mathrm{mass} \% \mathrm{ZrO}_{2}$. 
相対密度は急激に増加し, $950^{\circ} \mathrm{C}, 1000^{\circ} \mathrm{C}, 1050^{\circ} \mathrm{C}$ の各温度で 焼結した場合それそれ 0.5 mass\%, 0.75 mass\%, 1.0mass\%の ZrO 添加量で 98\%以上の高密度が得られた.このように緻密化に

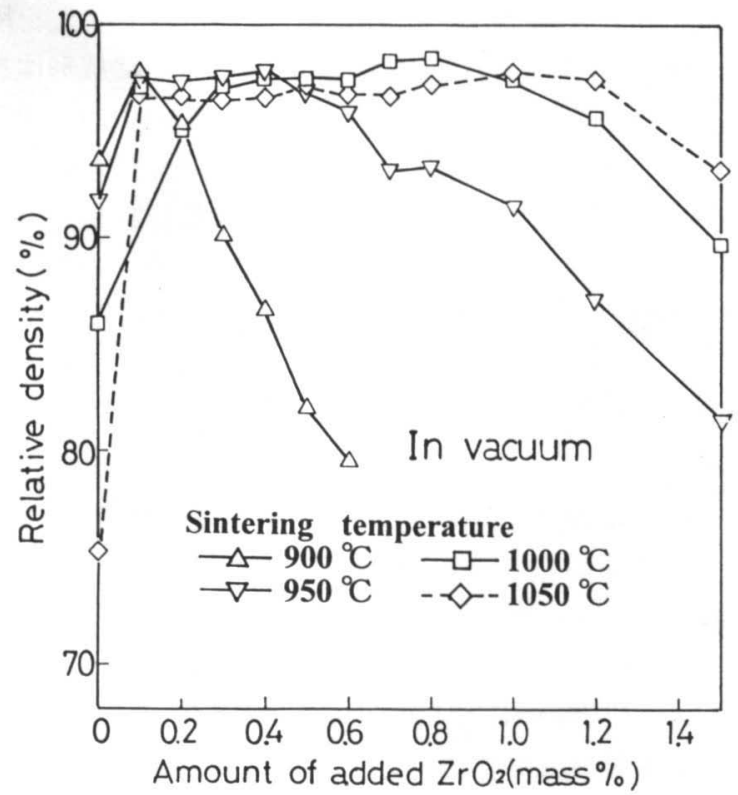

Fig.3 Relation between relative density and the amount of additive $\mathrm{ZrO}_{2}$ fine powder for $\mathrm{Cu}$ compacts sintered at the each temperature in vacuum.

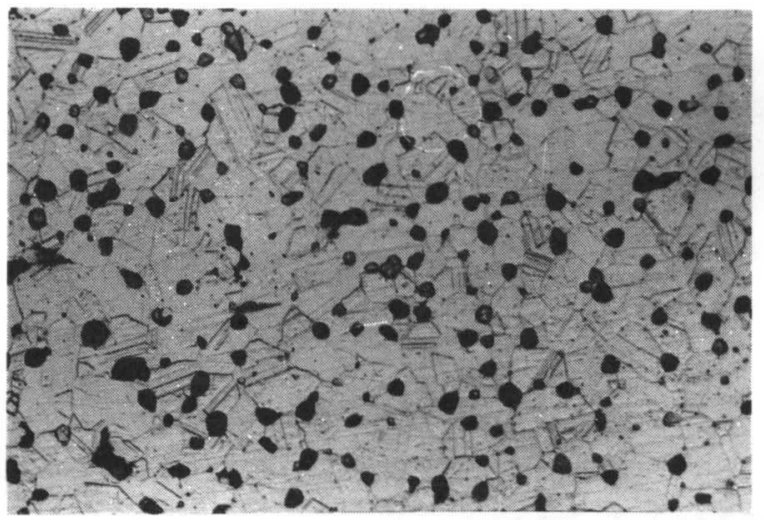

(a) without $\mathrm{ZrO}$, R.D.: $\mathbf{9 1 . 4 8 \%}$

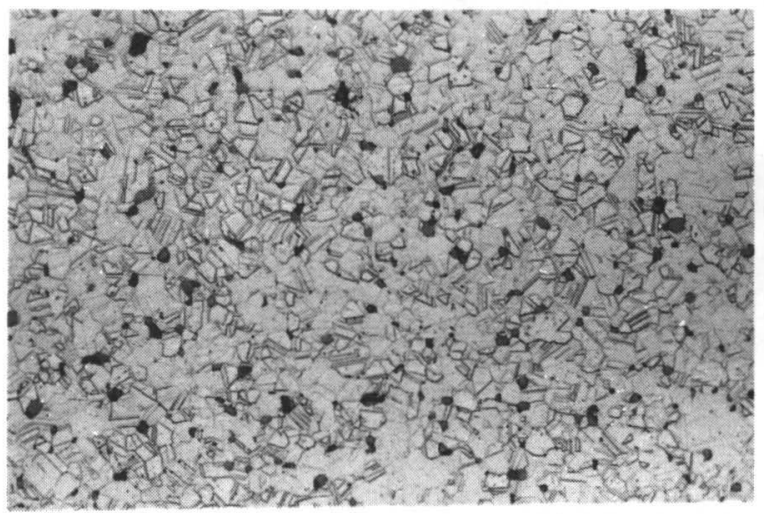

(c) 0.4 mass \%ZrO2, R.D.: $\mathbf{9 8 . 0 1 \%}$
最も効果的な $\mathrm{ZrO}_{2}$ 添加量は焼結温度が高くなるほど多くなる 傾向を示したが, いずれの場合も添加量がある量を超えると 急激に焼結性が悪くなることが分かる。

Fig.2に水素雾囲気中, $950^{\circ} \mathrm{C}$ で焼結した際の顕微鏡組織を 示した. $\mathrm{ZrO}_{2}$ 無添加の場合, 著しく粗大化した空隙が見られ 膨れが起こっているが, 0.2 mass\%の $\mathrm{ZrO}_{2}$ を添加することによ り粗大な空隙が消え縀密な組織になっていることわかる. 添 加量が 0.5 mass\%では空隙が少なくなるとともに結晶粒も細か くなり $\mathrm{ZrO}_{2}$ 微粉による結晶粒界のビン留め効果が見られる が, さらに $\mathrm{ZrO}_{2}$ の添加量加 0.7 mass\% と增加するとやや未焼 結の部分が出てくることがわかる.

Fig.3に真空中で各温度で焼結した際の焼結体の相対密度に 及ぼすZ $\mathrm{ZO}_{2}$ 添加量の影響を示した. 真空中焼結の場合は, $900^{\circ} \mathrm{C}$ $950^{\circ} \mathrm{C}$ では $\mathrm{ZrO}_{2}$ 無添加でも密度はかなり上昇するが, $1000^{\circ} \mathrm{C}$ 以上で焼結した場合は著しく密度は低下し膨れが起きている ことが示された. 真空焼結の場合は $0.1 \mathrm{mass} \%$ の $\mathrm{ZrO}_{2}$ の添加 で焼結緻密化には十分な効果が有り，97 98\%の高い相対密 度を示した. 密度はそれ以上の $\mathrm{ZrO}_{2}$ 添加量の増加に対しては ほほ一定の高い值を保つがさらに添加量か增加すると逆に急 激な低下を示した。

Fig.4に真空中で $950^{\circ} \mathrm{C} て ゙$ 焼結した組織に及ぼす $\mathrm{ZrO}_{2}$ の添加 量の影響を示した. 無添加の場合, $\mathrm{H}_{2}$ 䨌囲気中焼結の場合に

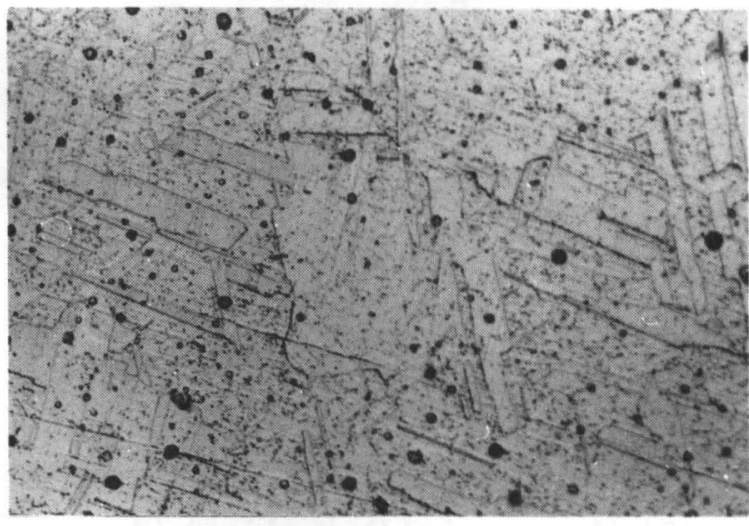

(b) 0.1 mass $\% \mathrm{ZrO}_{2}$, R.D.: $97.56 \%$

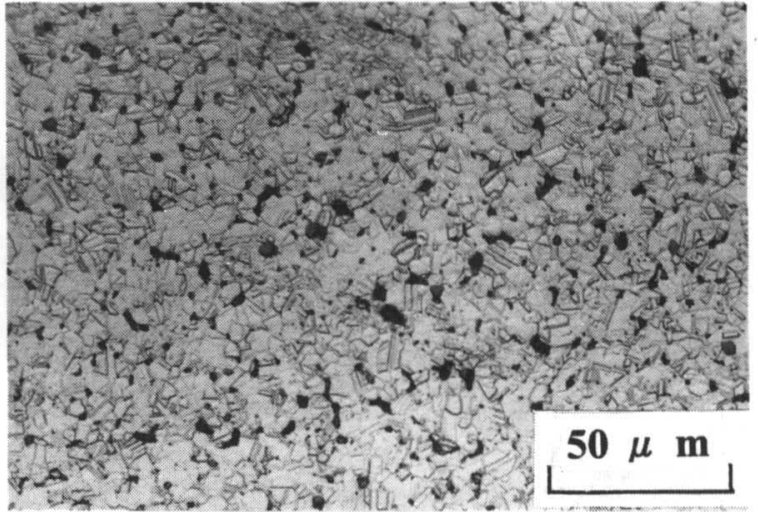

(d) 0.8 mass $\% \mathrm{ZrO}_{2}$, R.D.: $\mathbf{9 4 . 2 7 \%}$

Fig.4 Microstructural changes in $\mathrm{Cu}$ compacts sintered at $950^{\circ} \mathrm{C}$ in vacuum, where (a) without $\mathrm{ZrO}_{2}$, (b) $0.1 \mathrm{mass}^{2} \mathrm{ZrO}{ }_{2},(\mathrm{c}) 0.4 \mathrm{mass} \% \mathrm{ZrO}$, (d) 0.8 mass $\% \mathrm{ZrO}_{2}$. 
比較してかなり膨れの程度は小さいか，やや大きい球状の孤立 空隙が見られやはり膨れが起こっているのがみられる。 0.1 mass\%の $\mathrm{ZrO}_{2}$ 添加で空隙は極端に細かくなりまたその数も少 なくなり，0.4 mass\% $\mathrm{ZrO}_{2}$ 添加で空隙はさらに細かくなるとと もに結晶粒が微細化することが示される.またさらに $\mathrm{ZrO}_{2}$ 添 加量が増加すると結晶粒は微細化しているが空隙が不規則に なり末焼結の部分が多くなってくる.

$3.2 \mathrm{Cu}$ 粉の膨れ防止に及ほす $\mathrm{ZrO}_{2}$ 粉添加の効果に関する考察 $\mathrm{ZrO}_{2}$ 粉は高融点のセラミック粉で $1000^{\circ} \mathrm{C}$ 前後の温度では殆 ど焼結しない材料であり， $\mathrm{H}_{2}$ と反応して分解することもまっ たく無い安定な物質である.

また添加した $\mathrm{ZrO}_{2}$ がこの温度範囲で $\mathrm{Cu}$ と反応し，他の化 合物を形成するか否かを確かめるために, 5 mass\% $\% \mathrm{ZO}_{2}$ を添加 したCu粉を $1080^{\circ} \mathrm{C}$ で焼結した試料についてX線解析を行つ た.この結果, Fig.5(a)(b)で示すように焼結前後の回折線は 同じ形状を示し，とくに化合物のピークも見られないことか ら $\mathrm{ZrO}_{2}$ と $\mathrm{Cu}$ が反応を起こした形跡は見あたらなかった.

これらのことから $\mathrm{ZrO}_{2}$ 粉末が $\mathrm{Cu}$ 粉に対していわゆる焼結 活性化効果 ${ }^{2,3}$ を持つことは全く無いと考えられる:このため $\mathrm{ZrO}_{2}$ 粉のCu粉に対する編密化促進効果は次のような機構によ るものと考えられる. (1)添加した $\mathrm{ZrO}_{2}$ 微粉は $\mathrm{Cu}$ 粉末の間に 入り込むため粉末粒子表面の金属面どうしの接触面積を減少
させることになる.そのため急激な焼結が起こるのを抑えら れ空隙の孤立化を遅らせる.(2)同時にCuが焼結後もそのマト リックス中に分散したこの微粉か，通路を形成し発生したガ スを排出を助ける. 以上の理由で空隙の孤立化とその膨れが 防止されると考えられる.ただし(1)で $\mathrm{ZrO}_{2}$ の量が多すぎると Cu粒子の表面を全て覆ってしまうため焼結性が急速に悪くな り極端な密度低下につながると考えられる.ここで $\mathrm{H}_{2}$ 雾囲気 中での焼結の場合は膨れの原因となるガスは焼結中に残留し ていた微量の酸素が雾囲気の水素と反応して発生した $\mathrm{H}_{2} \mathrm{O}$ と 考えられる.一方，高真空中で焼結した場合においても $\mathrm{ZrO}_{2}$ 無添加の場合に膨れが起き, 添加することによって膨れが防 止されるか，この場合 $\mathrm{H}_{2} \mathrm{O}$ の発生は考えにくく，膨れの主原 因となるガスは他のものであると考えられる. $3.3 \mathrm{Cu}$ 焼結体の強度に及ほす $\mathrm{ZrO}_{2}$ 添加の影墼

Fig.6に $\mathrm{H}_{2}$ 雲团気中で焼結した焼結体の引張り強度と $\mathrm{ZrO}_{2}$ 添加量の関係を示した.Cu焼結体の強度は密度にほほ対応し て変化するが, $1050^{\circ} \mathrm{C} て ゙$ 焼結すると $\mathrm{ZrO}_{2}$ 添加量か5 1.5 mass\% で高強度を示した.これは $1050^{\circ} \mathrm{C} て ゙$ 焼結した場合, 添加量か 1.5 mass\%になってもなお $95 \%$ 以上の密度を保っていること と, Fig.7に示すように添加量が 0.5 mass\%から 1.5 mass\%に変 化すると結晶粒が極端に微細化するすることの他に, $\mathrm{ZrO}_{2}$ 微 粒子による分散強化奻果が起こることが考えられる.
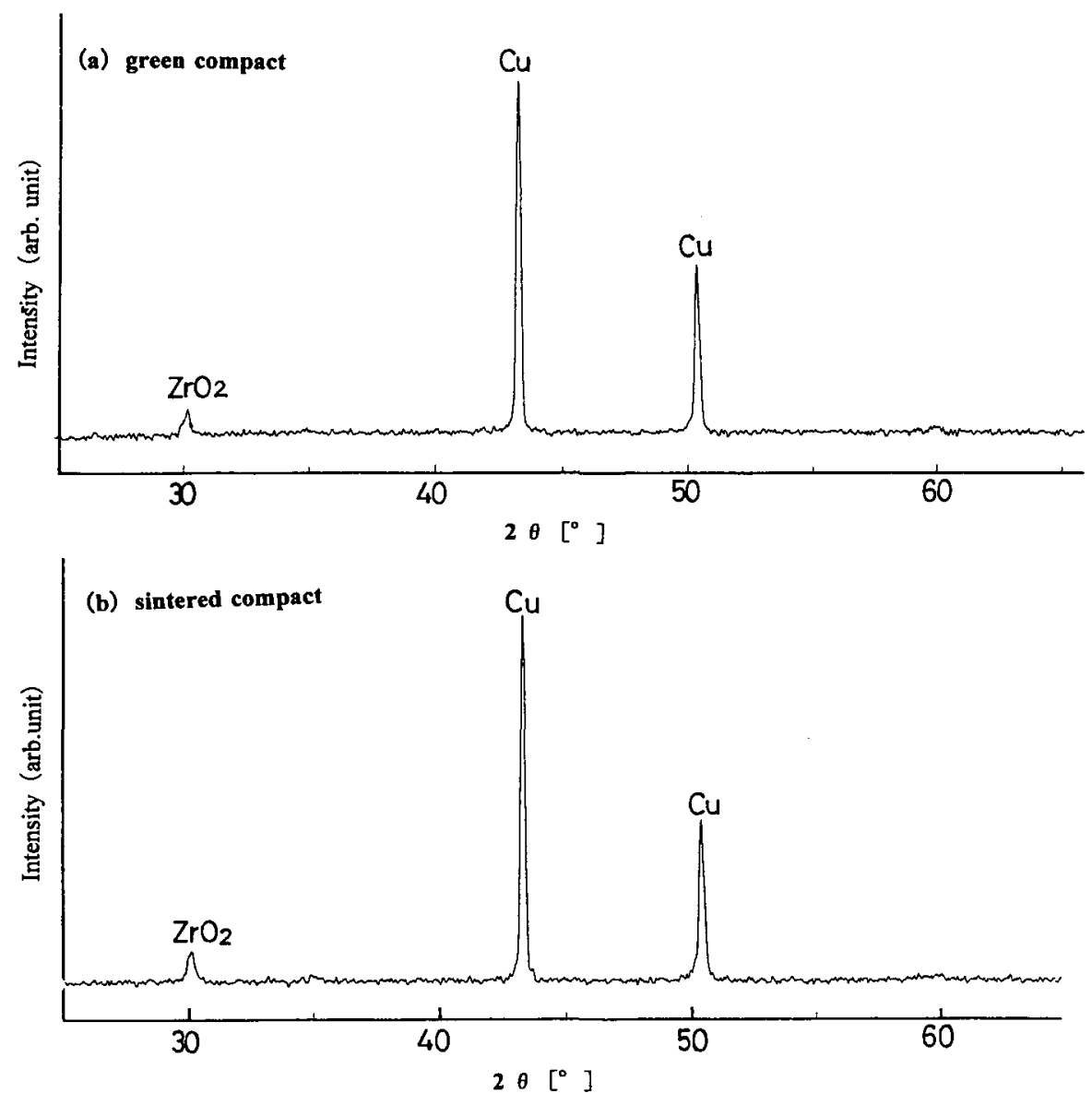

Fig.5 X-ray diffractions of (a) green compact and (b) sintered compact of $\mathrm{Cu}-5$ mass $\% \mathrm{ZrO}_{2}$ mixed powder. 


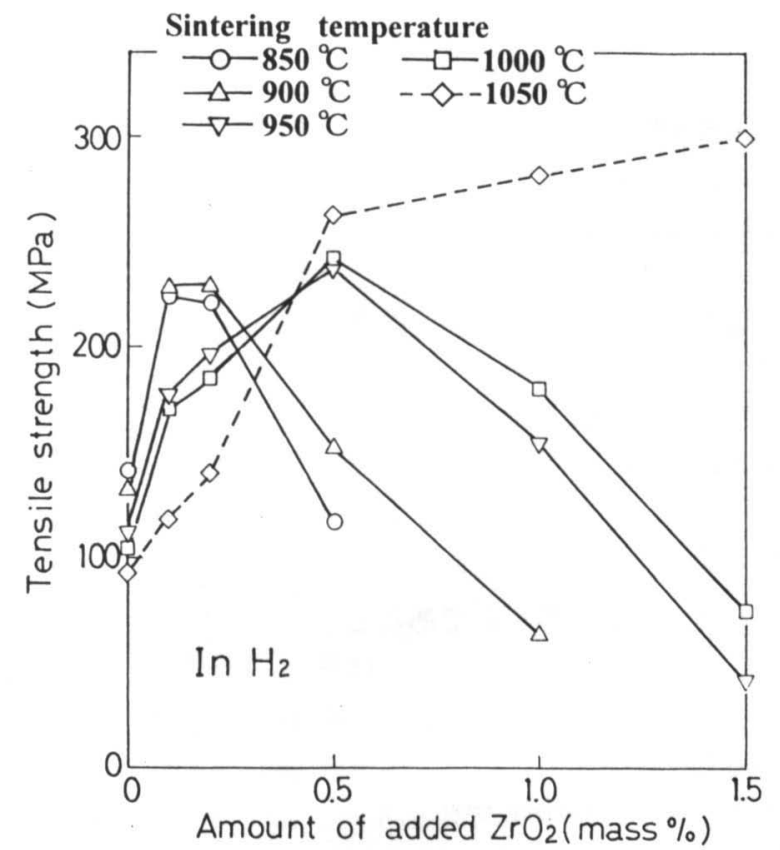

Fig.6 Relation between tensile strength and the amount of additive $\mathrm{ZrO}_{2}$ fine powder for $\mathrm{Cu}$ compacts sintered in $\mathrm{H}_{2}$.

\section{4 結論}

$\mathrm{ZrO}_{2}$ 微粉を添加した $\mathrm{Cu}$ 粉を焼結して次の結論を得た.

(1) $\mathrm{ZrO}_{2}$ 微粉の添加は $\mathrm{Cu}$ 焼結体の膨れ防止, 緻密化に非常に 効果的である.これはこの微粉が Cu粉どうしの焼結をや や鈍らせ孤立空隙の形成を遅らせるとともに閉じ込められ たガスが外部に拡散していく経路を形成するためと考えら れる。

(2) 焼結密度が最も高くなる $\mathrm{ZrO}_{2}$ の添加量は焼結温度が高く なるほど多くなる傾向を示した。

(3) $\mathrm{ZrO}_{2}$ 微粉の添加量を増加させることにより焼結体の密度は やや低下するが, 非常に細かい結晶粒を持つ組織が得ら れ，焼結体の強度も上昇した。

\section{文献}

1) 林台煥, 林宏爾: "射出成形用金属粉の焼結緻密化...", 粉体

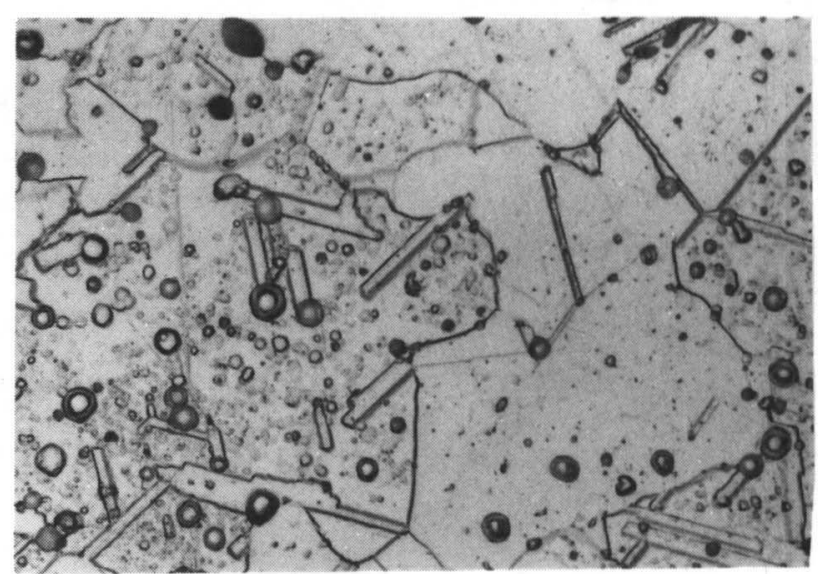

(a) $0.5 \mathrm{mass} \% \mathrm{ZrO}$, R.D.: $\mathbf{9 7 . 4 5 \%}$

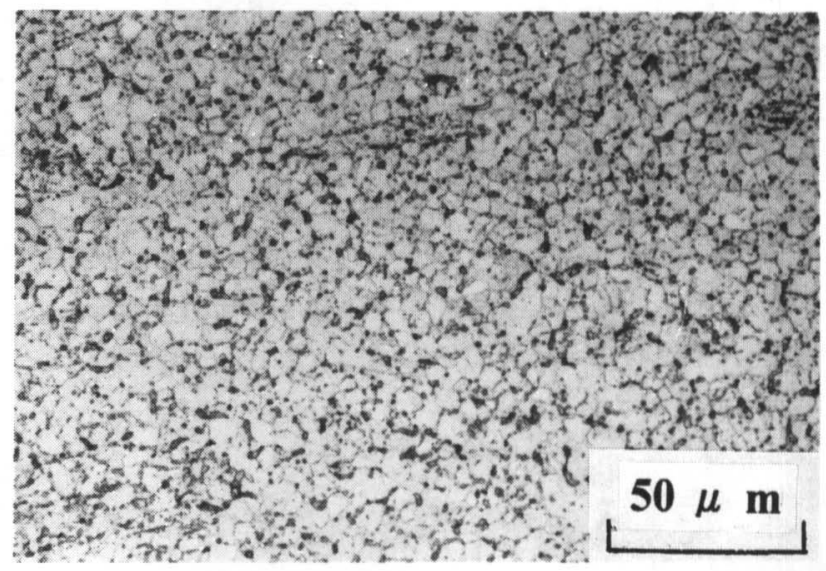

(b) $1.5 \mathrm{mass} \% \mathrm{ZrO}$, R.D.: $\mathbf{9 5 . 2 5 \%}$

Fig.7 Microstructures of $\mathrm{Cu}$ compacts sintered at $1050^{\circ} \mathrm{C}$ in $\mathrm{H}_{2}$, where (a) with 0.5 mass $\% \mathrm{ZrO}_{2}$, (b) with 1.5 mass $\% \mathrm{ZrO}_{2}$.

および粉末治金, 40(1993)373-378.

2) M.German and B.H.Rabin: "Enhanced sintering through second ...", Powder Met., 28(1985)7-12.

3) G.Petzow: "Sintering with Additives",粉体および粉末治金, 34(1987)235-247. 